follow are clear and well researched. Of special value is the brief chapter dealing with elements of uranium supply and demand, enrichment, reprocessing and nuclear waste. Here Camilleri juxtaposes with considerable clarity the history of the growth of nuclear power programmes in each of his six chosen countries; together with some of the other material in the book, this account will be a valuable reference source.

In contrast, the treatment of international nuclear politics touching on non-proliferation matters is sketchy, and at times misses the mark, mixing cause with effect or ascribing the wrong motives to policies. For example after going into substantial detail (pp.253-267) to describe the actions taken by the United States in support of the non-proliferation regime under President Carter's leadership, Camilleri dismisses the performance as "a situation from which US nuclear export policy sought to derive maximum advantage [p.288]', This evaluation runs contrary to most informed judgements that the Carter policy was, in fact, a colossal misapplication of means to ends - although with commendable motives - in support of the NPT. In fact, the United States lost nuclear-power-related business in international markets to other supplier countries which could furnish the technology and which got the orders as a direct result of Carter's policies.

Because Camilleri explicitly excludes from his book the nuclear power programmes behind the Iron Curtain, we do not get the full benefit of his considerable talents at digging out and organizing the events of recent history. Had he done so, I wonder whether he would not have stressed the West's democratic institutions instead of focusing on their capitalistic economies as the root cause of the troubles with their nuclear programmes - to my knowledge, there is no case where popular objections have been reported as having interfered with the prosecution of the nuclear programmes in the states with "centrallyplanned economies".

This is a substantive and provocative book which deserves a wide audience. As an academic and an economist, however, Camilleri seems to be writing exclusively for his peers, while his ponderous style with its overload of jargon demands a high degree of perseverance on the part of the reader. Equally, a shoddy publishing job - including proof-reading errors and uneven, over-compressed typography -has made the book uncomfortable going. But none of these points should be allowed to detract from Camilleri's scholarly analysis of some of the most pressing problems now facing those democratic nations pursuing nuclear power programmes.

Eli B. Roth is a consultant on energy technology and policy, and a Visiting Fellow at Yale University.

\section{Growth of an infant science}

\section{S.D. Wratten}

Insects on Plants: Community Patterns and Mechanisms.

By D.R. Strong, J.H. Lawton and Sir

Richard Southwood.

Blackwell Scientific/Harvard University

Press: 1984. Pp.313. Hbk £22, \$35; pbk

f11.80, $\$ 18$.

ON THE last page of this book, the ecology of insect-plant interactions is dubbed "our infant science". The phrase is a good guide to the excitement and frustrations of working in this research area in the 1980s. The excitement, which the book certainly reflects, comes from the frequency with which a few empirical but well-conducted experiments have produced far-reaching ideas demanding further testing. The frustrations are the familiar ones of having insufficient time and manpower to test the hypotheses which are produced by a burgeoning discipline.

I read the book on an otherwise tedious journey on a slow Spanish train and my attention was held throughout. However, it is the sort of book that also demands that the reader put it down at frequent intervals, simply because, like all good textbooks, it asks questions. Those it asks most penetratingly concern the frequency and importance of competition between plantfeeding insects and the role of coevolution as a driving force in plant-herbivore relationships. Having posed the questions, the authors do not shrink from attempting to answer them, sometimes with a conviction which belies the tender age of the subject.

One of the current debates is over how often plant resources are limited to such an extent that insect species compete for them. The authors consider this inter-specific competition to be a rarity, and are more impressed with the apparent evidence that predators and parasitoids keep insect numbers below levels at which competition occurs. They review published life-table analyses of populations of phytophagous insects and show that even cases of intraspecific competition (a necessary precursor of inter-specific competition) are outnumbered $2: 1$ by those of predation as factors acting in a density-dependent way, that is factors which increase the proportional mortality they impose as populations increase. Support for the premise that plant-feeding insect species rarely compete is taken also from the "stunningly simple logic" of Hairston et al. (Am. Nat. 44, 421-425; 1960) who argued that

obvious depletions of green plants by herbivores are exceptions to the general picture that green plants are abundant and largely intact. The only possible remaining general method of control is predation ... including parasitism. Herbivores are ... therefore not likely to compete for common resources.

What is intuitively logical is not always correct, however, as the statistician G.E. Yule implied when he wrote that "Logic and Mathematics are only of service ... once you have found the right track". Another review of a different set of population analyses has indicated that there is, indeed, a different track which could be followed. J.P. Dempster (Biol.Rev. 58, 461-481; 1983) surveyed 24 studies of moth and butterfly populations and concluded that intra-specific competition was the only density-dependence operating in 13 cases, with natural enemies exhibiting density dependence in another three. These cases of intra-specific competition usually involved clear depletion of food resources but recent work (much of which has appeared since this book was written) has added extra evidence that apparent super-abundance of acceptable food may not be the norm.

This topic, given only half a page in the book, concerns the role of feeding-induced changes in plants following insect feeding. If such "induced defences" are common they could lead to an increasing proportion of a plant's leaves becoming unsuitable as grazing by an insect population progresses, forcing competition upon individuals when crude measures of foliage biomass would still indicate an apparent super-abundance. C. West, for example, in a paper to be published (Ecol. Ent. 10; 1985), shows that oak leaf miner larval fitness is reduced if the larvae feed on leaves which have earlier sustained normal levels of caterpillar damage. These results point to temporal competitive exclusion between the mining and chewing guilds; if they represent hitherto under-investigated interactions, they cast doubt on the premise that interspecific competition among phytophages is a rarity.

The ecological importance and topicality of these questions confirm that the time is certainly right for this book. The fact that the authors take definite stances on controversial areas make it stimulating reading. Final-year undergraduates and postgraduates are bound to enthuse about the clarity of writing and the layout, the attractive use of vignettes in the figures and - above all - about the excitement which this book conveys about "our infant science" and its future.

S.D. Wratten is a Lecturer in the Department of Biology, University of Southampton.

\section{Biotechnology in America}

Edward Yoxen's The Gene Business: Who Should Control Biotechnology?, an examination of the environmental, industrial and social ramifications of genetic engineering, has been published in the United States by Harper \& Row. Price is $\$ 15.95$. The original edition of the book, a paperback published in Britain by $\mathrm{Pan}$ (£3.95), was reviewed in Nature 304, 285; 1983. 